\title{
Judicial Capacity Building in Bosnia and Herzegovina: Understanding Legal Reform Beyond the Completion Strategy of the ICTY
}

\author{
Lilian A. Barria - Steven D. Roper \\ (C) Springer Science + Business Media B.V. 2007
}

\begin{abstract}
This article examines how international institutions serve to diffuse human rights norms and create judicial capacity building in post-conflict societies. Specifically, we examine how the International Criminal Tribunal for the former Yugoslavia (ICTY) and the Office of the High Representative have influenced the reform of domestic courts in Bosnia and Herzegovina (BiH). We place these reforms within the broader debate over restructuring the complex system of government in $\mathrm{BiH}$. Since 2005, domestic courts in $\mathrm{BiH}$ have had jurisdiction over the following: (1) Cases which were initially under the jurisdiction of the domestic courts but remanded to the ICTY and recently returned to $\mathrm{BiH}$. (2) Cases which originated at the ICTY and have been transferred to the State Court, and (3) new cases which originated and remained in the domestic court system. We find that while human rights norms have been incorporated into the new legal code, the diffusion of these human rights norms has been inadequate because of the lack of judicial capacity building. While some courts in the capital enjoy significant resources, the vast majority of cases will be tried at provincial courts which are under-funded and unable to prosecute the significant number of cases. Moreover, the government structure of $\mathrm{BiH}$ has had a decidedly negative impact on the prosecution of these cases. Ultimately, the rule of law requires consistency of approach and funding to protect human rights throughout the state.
\end{abstract}

The Completion Strategy of the International Criminal Tribunal for the former Yugoslavia (ICTY) has brought renewed attention to war crimes prosecutions in Bosnia and Herzegovina (BiH). Passed in 2003, United Nations (UN) Security Council Resolution 1503 affirmed the Completion Strategy of the ICTY with

\footnotetext{
L. A. Barria $(\bowtie) \cdot$ S. D. Roper

Department of Political Science, Eastern Illinois University, 600 Lincoln Ave, Charleston, IL 61920, USA

e-mail: labarria@eiu.edu

S. D. Roper

e-mail: sdroper@eiu.edu
} 
investigations ending by 2004 , trials by 2008 , and appeals by 2010 . To maintain the timeline for ending all proceedings at the ICTY, a major component of the Completion Strategy called for the devolution of cases to national judiciaries in the former Yugoslavia, including Croatia and especially BiH. Resolution 1503 notes that:

the strengthening of national judicial systems is crucially important to the rule of law in general and to the implementation of the ICTY and ICTR Completion Strategies in particular...an essential prerequisite to achieving the objectives of the ICTY Completion Strategy is the expeditious establishment...and early functioning of a special chamber within the State Court of Bosnia and Herzegovina (the "War Crimes Chamber") and the subsequent referral by the ICTY of cases of lower- or intermediate-rank accused to the Chamber.

The devolution of cases to the $\mathrm{BiH}$ domestic judiciary has required the international community to evaluate the ability of these courts to adjudicate cases transferred from the ICTY. Aside from assisting the ICTY with its workload, transferring cases has also been seen as a means to increase the transparency of the domestic judicial process, promote the rule of law, dispel notions of bias in the prosecution of ethnic Serbs, and enhance the overall level of public confidence in state-level prosecutions.

However, even as the return of cases to $\mathrm{BiH}$ was being contemplated by the international community, those within the ICTY recognized that strengthening the domestic judiciary would be vital to ensure the integrity of the process. For example, in his address to the Security Council on 27 November 2001, ICTY President Claude Jorda indicated that the Tribunal was considering transferring lower-level cases to the domestic courts in the former Yugoslavia only with assurances that the trials would meet international standards of fairness and due process. While these concerns have been expressed in relation to transferred cases from the ICTY, these cases actually represent a very small number of the war crimes trials that have been and will be tried in $\mathrm{BiH}$. During the period from 1992 to 2006, approximately 13,000 persons have been reported as possible defendants in war crimes cases (High Judicial and Prosecutorial Council 2006).

To deal with the enormous domestic caseload as well as the ICTY transferred cases, the Office of the High Representative (OHR), which is the primary civilian international implementation agency in $\mathrm{BiH}$, proposed in 2003 several amendments to the $\mathrm{BiH}$ legal system including the adoption of a new criminal code $(\mathrm{CC})$ and criminal procedure code (CPC) for $\mathrm{BiH}$, as well as the creation of a War Crimes Chamber (WCC) within the State Court of BiH to try transferred ICTY cases. ${ }^{1}$ While approximately 14 transferred ICTY war crimes cases will eventually be tried at the WCC, cantonal and district courts throughout the country will be responsible for trying literally thousands of other war crimes cases. The ultimate success of the domestic process for prosecuting war crimes will not only depend on the

\footnotetext{
${ }^{1}$ The BiH Criminal Code includes the offenses that can be tried before courts as well as sentencing guidelines for each type of offense. The $\mathrm{BiH}$ Criminal Procedure Code covers court proceedings, including prosecutorial and defense guidelines, suspect rights and witness protection. 
achievements of the WCC but also on the ability of these other courts to fairly prosecute these cases.

In this article, we examine the development of the judiciary in $\mathrm{BiH}$, with particular attention to its evolution since the end of the war in 1995 . We provide an overview of the legal structure in $\mathrm{BiH}$, the different types of war crimes cases to be adjudicated, the legal process in which war crimes cases are tried, and the role played by different institutions, including the ICTY and the OHR in the promotion of justice and the rule of law. While there has been considerable attention paid to the Completion Strategy of the ICTY as it impacts national judiciaries, far less attention has been focused on efforts of local judicial capacity building within the successor states of the former Yugoslavia. Particularly in the case of $\mathrm{BiH}$, efforts to enhance the professionalism and efficiency of the judiciary must be placed within a broader discussion concerning the structure of the government. Indeed, part of the difficulty in creating an efficient and an impartial legal system in $\mathrm{BiH}$ has involved the complex structure of government institutions resulting from the Dayton Peace Agreement.

\section{Understanding the Structure of the Judiciary in $\mathrm{BiH}$}

The 4-year war in the former Yugoslavia was brought to an end by the signing of the Dayton Peace Agreement in December 1995 which created a post-war constitutional structure for $\mathrm{BiH}$ in which the state consists of two entities: The Federation of Bosnia and Herzegovina (FBiH) and the Republika Srpska (RS). Both the FBiH and the RS have a strong degree of autonomy from the national (state) level with their own ministries of justice and interior. The $\mathrm{FBiH}$ is composed of 28 municipal courts which adjudicate lower-level cases, 10 cantonal courts which have jurisdiction over war crimes cases and an appeals court (Supreme Court), and Constitutional Court (see Fig. 1). The RS structure mirrors the FBiH - the 19 basic courts hear lesser offenses, while the five district courts have jurisdiction over war crimes cases. In 1999, the Brcko District was allowed self-government and a separate court system (American Bar Association 2001). Until 2003, the cantonal courts (FBiH), district courts (RS), and the basic court of Brcko District had exclusive (original) jurisdiction to hear first instance war crimes trials in $\mathrm{BiH}$. In these courts, war crimes cases can be appealed to the Supreme Court in the respective entity (or to the Brcko Appellate Court).

At the national or state level, there have been established a number of judicial institutions including the Constitutional Court (1995), Human Rights Commission $(1995)^{2}$, and the State Court of $\mathrm{BiH}$ (2000). The State Court has first instance jurisdiction over administrative matters (for example, disputes related to electoral law) and second instance jurisdiction (appellate jurisdiction) over criminal matters in $\mathrm{BiH}$. As part of the State Court, the WCC was created in 2003 to handle transferred cases from the ICTY. The WCC does not have jurisdiction over entity-level courts

\footnotetext{
${ }^{2}$ The Human Rights Commission was established as part of the Dayton Peace Agreement. The Commission's mandate ended in December 2003, and cases were transferred to the Constitutional Court's Human Rights Commission. This Commission's mandate ended in December 2004.
} 


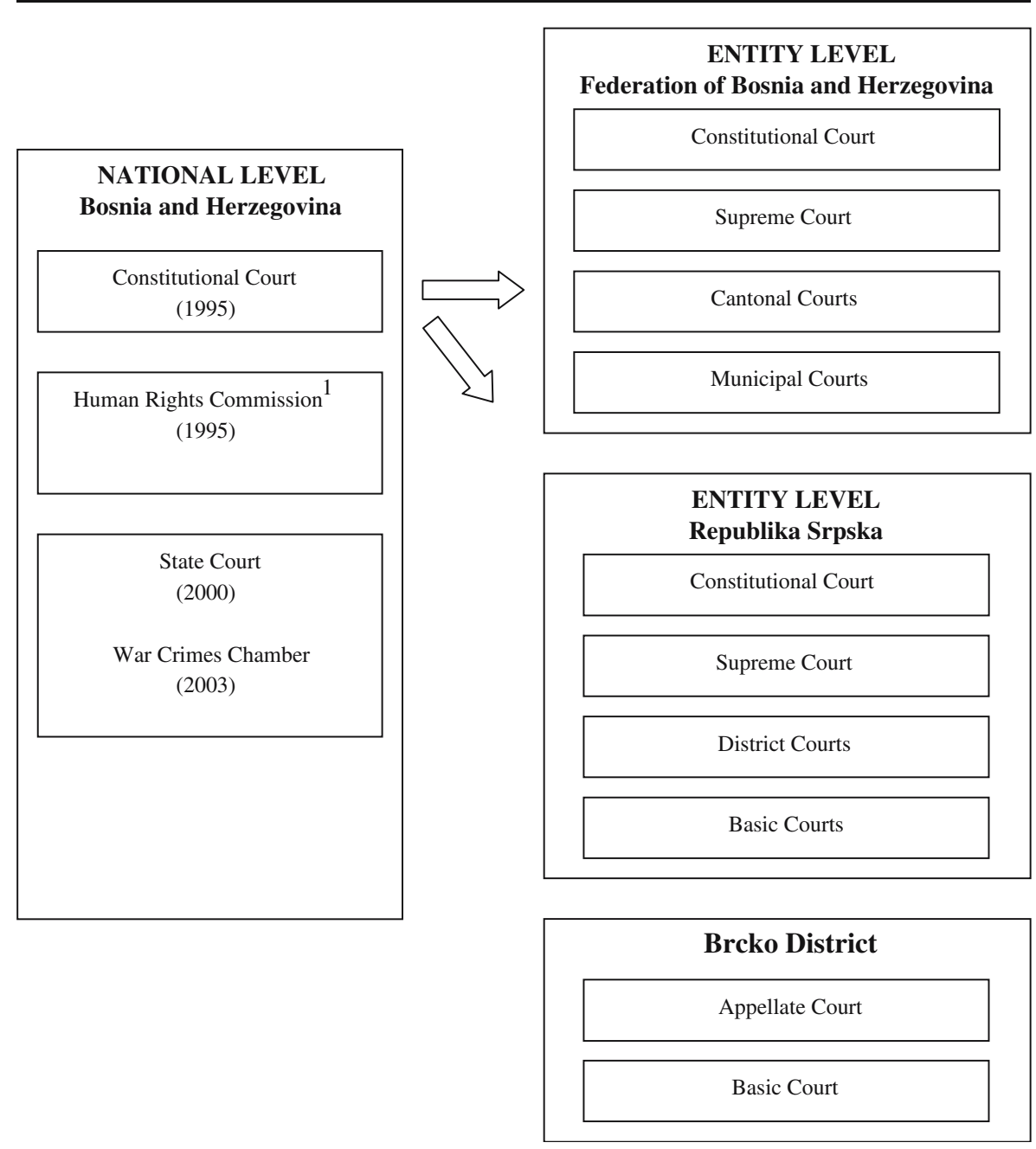

Fig. 1 Judicial Structure in Bosnia and Herzegovina since 1995. While the arrows indicate that the Constitutional Court has jurisdiction over the entity-level courts, it has generally ruled on rather limited constitutional issues. As a consequence, the Constitutional Court is not viewed as authoritative in areas of international humanitarian and human rights law.

${ }^{1}$ The mandate of the Human Rights Commission ended on 31 December 2003. It transferred its responsibilities to the Constitutional Court's Human Rights Commission. This Commission's mandate ended in December 2004

(those in the FBiH and the RS), and the WCC appellate chamber can only hear cases which originated in the WCC.

The Constitutional Court of $\mathrm{BiH}$, which was the only state-level court until 2000, may receive appeals against decisions from any court where there are allegations of a violation of the constitution, including cases involving human rights, and the Court also has the authority to decide whether a provision of an entity constitution is inconsistent with the $\mathrm{BiH}$ Constitution. While this Court has de jure jurisdiction over all courts in the country, it has generally ruled on limited constitutional issues rather than on broader issues of human rights. As a consequence, the Constitutional Court 
Table 1 Development of state-level judicial institutions

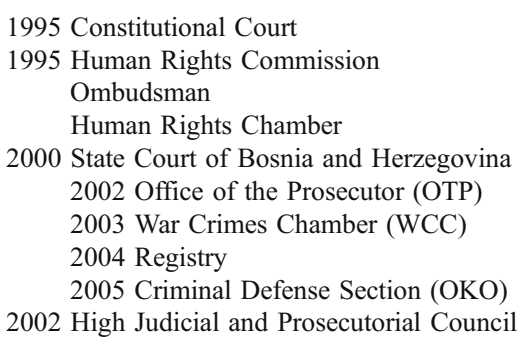

is not viewed as authoritative in areas of international humanitarian and human rights law. The lack of authority of the Constitutional Court in these areas leaves a vacuum in which no court in the judicial structure is viewed as superior; instead on war crimes issues, the national-level court system functions in parallel with the entity-level courts. This creates a myriad of problems concerning the value of precedent, application of criminal code procedures, and sentencing uniformity which we address later (Table 1).

\section{War Crimes Cases in BiH: Rules of the Road Cases}

There are currently three types of war crimes cases which can be prosecuted in $\mathrm{BiH}$ : (1) Cases which originated in $\mathrm{BiH}$ but were reviewed by the ICTY and returned to $\mathrm{BiH}$ (so-called Rules of the Road or RoR cases). (2) Cases originating in $\mathrm{BiH}$ which were never part of the RoR review process at the ICTY, and (3) transferred ICTY cases, or 11bis cases, referred back to $\mathrm{BiH}$ for prosecution as part of the ICTY's Completion Strategy (Lauth 2005). While most of the focus of the international community has centered on the 161 individuals that have been part of the process at the ICTY, BiH domestic courts began issuing indictments and conducting trials even before the creation of the ICTY. For example, the Organization for Security and Cooperation in Europe (OSCE) reports that between 1993 and 1995 in the military court in the Municipality of Orašje in $\mathrm{FBiH}, 47$ suspects were convicted in absentia, with several receiving the death sentence. ${ }^{3}$ The arbitrary arrests and unfair trials had a chilling effect on the return of civilians to their homes as well as travel throughout $\mathrm{BiH}$. As the Dayton Peace Agreement envisioned the return of refugees and displaced persons, it was critical that a process be established to assist the domestic courts in meeting international standards of justice.

As part of the Rome Agreement signed in February 1996 by the presidents of $\mathrm{BiH}$, Croatia and the Federal Republic of Yugoslavia, a RoR procedure was introduced to ensure that the national courts met international legal standards. The RoR procedure required that entity authorities in $\mathrm{BiH}$ submit their cases to the

\footnotetext{
${ }^{3}$ The Organization for Security and Co-operation in Europe has been monitoring trials for a number of years. For more information see, $\operatorname{OSCE}(2005 \mathrm{a}, \mathrm{b})$.
} 
ICTY's Office of the Prosecutor (OTP) for approval before the indictment and the arrest of suspects (or the continuing detention of suspects). ${ }^{4}$ Between 1996 and 2004, the ICTY's RoR unit reviewed files for 5,789 suspects with 3,489 cases referred back to the entity authorities (OSCE 2005a, 6).

Most cases reviewed by the ICTY's RoR unit and referred back to entity authorities were categorized as either "A," "B", or "C." Category A referrals indicated that the evidence against the suspect was sufficient to justify the indictment. Category B referrals indicated that the evidence was insufficient to meet international standards, while Category $\mathrm{C}$ cases indicated that the RoR unit was unable to determine whether there was sufficient evidence in which case the entity authorities could gather additional evidence and resubmit the case for recategorization (Roper and Barria 2006). The vast majority of cases which were referred back to entity authorities were categorized as "B." Of the 3,489 cases that were referred, 846 cases were categorized as "A" while 2,346 were categorized as "B" and 675 as "C." According to statistics provided by the ICTY, approximately 2,300 cases were never categorized by the RoR unit.

The implementation of the RoR procedure is credited with reducing the incidence of unjustified detention; however, one of the unintended consequences has been that it slowed down or even stopped the prosecution of many domestic war crimes cases. Indeed, relatively few domestic trials have been completed, and therefore, many suspects have remained at large. According to the OSCE, between 1996 and January 2005, only 54 Category "A" cases against 94 defendants had reach the trial stage in $\mathrm{BiH}$, and of these, only 41 cases have been completed (OSCE 2005a). While the situation in the $\mathrm{FBiH}$ is considered to be much better, by "contrast to the Federation, the RS has made little progress on war crimes prosecutions and has conveyed its lack of interest in, if not hostility towards them" (Zoglin 2005, 49). In the case of the $\mathrm{RS}$, there are concerns whether local government leaders are committed to the prosecution of these crimes, as the perception remains that the RS is the last vestige of "Greater Serbia" and that the prosecution of ethnic Serbs is incompatible with the political objectives in Banja Luka and in Belgrade.

Almost a decade after the end of the war, a large number of cases in $\mathrm{BiH}$ had not been prosecuted in the entity courts. One of the reasons for the relatively small number of trials has been that when cases were referred back to BiH, the ICTY never stipulated the territorial jurisdiction of the case (i.e., where the case had to be tried). Immediately after the war, many cases were investigated outside a court's jurisdiction, as witnesses were reporting events as they were internally displaced or as they fled $\mathrm{BiH}$. The ICTY referred cases back to the court which submitted the application for review, and as the OSCE notes " $[\mathrm{b}]$ ecause $\mathrm{BiH}$ was so ethnically divided in the aftermath of the conflict, the respective authorities had little faith that cases returned to the courts with appropriate jurisdiction would proceed to trial effectively or at all" (OSCE 2005a, 15). Generally, those trials which have occurred via the RoR process try the ethnic minority in the region in which the case was initiated, so the "trials were politically explosive, especially as various past and

\footnotetext{
${ }^{4}$ The Rules of the Road unit was staffed with international and domestic attorneys.

${ }^{5}$ There were a total of eight categories.

钐 Springer
} 
present national leaders were among those indicted or likely to be indicted" (Bohlander 2004, 4).

As part of the Completion Strategy, the ICTY transferred the RoR review process to state-level authorities in $\mathrm{BiH}$ in 2004. Transferring the RoR procedure to $\mathrm{BiH}$ relieved the ICTY of the responsibility of reviewing thousands of more cases. Therefore, the OTP at the State Court initially reviewed all "A" cases received from the ICTY, and 202 cases were classified as "very sensitive" and to be tried at the state level. The review of Category "A" cases was completed in May 2005, and since then, prosecutors in canton and district courts have had to submit an application for review to the State Court OTP for cases which were not categorized by the ICTY and in which there is no indictment. While this has created greater uniformity, as the State Court OTP has attempted to apply a consistent standard for review to all the devolved cases, the consequence is that either entity-level courts have stopped all criminal proceedings waiting for a decision from the State Court's OTP or they have used the review process as an excuse not to begin or continue their investigations. The unfortunate effect of the review process has been to slow down the trials at the entity level which were already piecemeal to begin with. ${ }^{6}$

\section{War Crimes Cases in BiH: The 11bis Cases}

Until 2003, the prosecution of war crimes took place exclusively at the entity level in $\mathrm{BiH}$ (i.e., the cantonal courts of the $\mathrm{FBiH}$ and the district courts of the RS) rather than at the state level. While the State Court of $\mathrm{BiH}$ was created in 2000, it did not have jurisdiction over war crimes cases until the creation of the WCC and the passage of the new CC and CPC in 2003 (see Fig. 1 and Table 2). While some argue that the State Court of $\mathrm{BiH}$ is "one of the key institutions in the process of the establishment of the rule of law in $\mathrm{BiH}$," the reality is that the Court was not established with jurisdiction over entity-level courts and is not regarded as a superior court within the BiH judicial structure (Registry 2005, 11).

However, one positive aspect of the ICTY Completion Strategy was that it created a momentum for reforming the $\mathrm{BiH}$ judicial system at the state level. As the ICTY began to consider the feasibility of transferring lower-levels cases to national courts, a commission of experts established by the OHR examined the forum in which the trials should occur. The expert report which was released in May 2002 contained a number of recommendations involving strengthening judicial institutions as well as noting areas of concern regarding witness protection and legal procedures (Bohlander 2003). To be able to meet the challenges of prosecuting both transferred ICTY cases as well as RoR cases, the OHR proposed several amendments to the $\mathrm{BiH}$ legal system as well as to the judicial structure which would impact not only the cases transferred from the ICTY but also the cases taking place before cantonal and district courts. The State Court OTP became operational in January 2003, and in February 2003, the OHR and the ICTY issued a joint decision regarding the necessity for the

\footnotetext{
${ }^{6}$ Interview with Toby Cadman, Head of the Prosecution Support Section, Special Department for War Crimes of the Prosecutor's Office of the State Court, Sarajevo, 19 July 2006.
} 
Table 2 Development of criminal codes and procedures, 1997-2003

Bosnia and Herzegovina (national level)

1977 Criminal Code of the Socialist Federal Republic of Yugoslavia

1998 Criminal Code of the Federation of Bosnia and Herzegovina

2000 Criminal Code of Republika Srpska

Criminal Code of Brcko District

2003 Criminal Code of Bosnia and Herzegovina

Criminal Procedure Code of Bosnia and Herzegovina

Criminal Code of the Federation of Bosnia and Herzegovina

Criminal Code of Republika Srpska

creation of the WCC within the State Court. The WCC's jurisdiction would include not only ICTY transferred cases but also the "most sensitive" cases in the country.

The effort to provide international assistance for the WCC led to a donor's conference in October 2003. At the conference, $€ 16.1$ million were pledged for the construction and staffing of the WCC for the first 2 years. ${ }^{7}$ The international funding of the WCC created modern courtrooms and provided for a well-trained staff composed of international and domestic legal advisors. To provide assistance and training to local judges and prosecutors, the WCC was established as a hybrid court in which the trial and the appellate chamber consist of two international judges and one domestic judge who preside over the chambers. There are currently 16 international judges within the State Court of $\mathrm{BiH}$ and a majority of seven international prosecutors in the OTP. The chambers and the OTP will later evolve into a majority of domestic judges and prosecutors with the final phase to be completed within 5 years of exclusively domestic judges and prosecutors. ${ }^{8}$ However, the question remains whether a hybrid court is the best approach to try war crimes cases in BiH. According to Carla Del Ponte, Chief Prosecutor of the ICTY, a hybrid court limits the ability of judges and prosecutors to share information and to discuss cases because of language barriers as well as different legal backgrounds and traditions. ${ }^{9}$

Even with these concerns in September 2005, the ICTY certified that the State Court in BiH, the OTP and the state level Ministry of Justice met international standards, and the first case from the ICTY was transferred to the WCC. The transfer of Radovan Stankovic to the WCC in September 2005 was the first of 14 cases scheduled to be transferred to the WCC. While these 11 bis cases will be tried at the WCC, the ICTY retains primary jurisdiction over these cases and can decide to take back a case if it believes that the WCC cannot conduct a proper trial.

\footnotetext{
${ }^{7}$ Another donor conference in March 2006 did not reach the targeted pledge amount for the next 3 years of funding.

${ }^{8}$ For a complete discussion of the creation of the War Crimes Chamber including administrative and financial issues, see Office of the High Representative (2004).

${ }^{9}$ In interviews at the International Criminal Tribunal for the former Yugoslavia, Carla Del Ponte was especially critical of the use of a hybrid court specifically because of linguistic incompatibilities and the differences in legal traditions which made the work of the War Crimes Chamber far less effective. Interview with Carla Del Ponte, Chief Prosecutor, International Criminal Tribunal for the former Yugoslavia, The Hague, 12 July 2006.
}

望 Springer 


\section{War Crimes Cases in BiH: The Diffusion of Legal Norms}

Also, as part of the legal reform process in $\mathrm{BiH}$, a new $\mathrm{CC}$ and $\mathrm{CPC}$ were introduced in March 2003 (see Table 2). The new codes made several changes in the trial process as well as court jurisdiction. For example, the new CPC abolished the position of investigating judge and placed these powers in the hands of the prosecution (a movement away from the inquisitorial trial process under the old Yugoslavian criminal code). At the same time, the OHR also required the reappointment of all judges and prosecutors. This task was the responsibility of the newly created High Judicial and Prosecutorial Council (which is part of the statelevel system as shown in Fig. 1). The Council also oversaw the restructuring of the courts and the entity-level OTPs throughout the country (for example, the number of first instance courts in both the FBiH and the RS were reduced from 78 to 47). Another important change to the legal code included a provision regarding plea bargaining which was viewed as a necessary device to process the thousands of cases which were pending throughout the system.

In addition, the new $\mathrm{CPC}$ established that the State Court of $\mathrm{BiH}$ has the right to review all entity-level war crimes cases to determine whether it wants to retain the case. ${ }^{10}$ This means that since March 2003, any new allegation of war crimes should be reported to the BiH's OTP by entity-level prosecutors. This is problematic, as the State Court is also supposed to continue the RoR process of reviewing older cases that were sent back from the ICTY which were never reviewed or not classified as Category "A." Therefore, the State Court OTP can review four types of war crimes cases: (1) Those cases which were returned to $\mathrm{BiH}$ as Category "A" (2) as well as RoR cases which were not classified as Category "A" or (3) were never reviewed by the ICTY, and (4) new cases originating in $\mathrm{BiH}$. This creates an enormous backlog of reviews at the State Court, particularly as prosecutors across $\mathrm{BiH}$ recorded 1,203 new cases with 7,720 defendants in 2005 (High Judicial and Prosecutorial Council 2006). Officials at the state level concede that the OTP will have to return thousands of cases to the entity level. ${ }^{11}$

While the WCC will prosecute the most sensitive war crimes cases in $\mathrm{BiH}$, it should not be viewed as a "superior" court to the other courts. Instead, it functions alongside the other courts, and this is one of the significant problems in $\mathrm{BiH}$ when it comes to ensuring that all parties involved have the requisite expertise to conduct proceedings. The Appellate Chamber of the WCC does not hear appeals from other courts and can only rule on cases in which the WCC has first instance or original jurisdiction.

Moreover, part of the problem in $\mathrm{BiH}$ entity courts in creating a uniform standard for the prosecution of war crimes cases has involved the ambiguity whether to apply the new or the old CC. Depending on the date of the confirmation of the indictment, some judges have been conducting trials in accordance with the old $\mathrm{CC}$ which

\footnotetext{
${ }^{10}$ However, Article 449 of the BiH Criminal Procedure Code of 2003 stipulates that the State Court Office of the Prosecutor can only review cases from the entity level in which an indictment has not been confirmed.

${ }^{11}$ Interview with Azra Miletic, President of the War Crimes Chamber Appellate Chamber, Sarajevo, 18 July 2006.
} 
creates significant differences in sentencing. For example, the $2003 \mathrm{CC}$ sentencing guidelines stipulate a maximum sentence of 20 years for war crimes. However, the law applicable across the territory of $\mathrm{BiH}$ for acts committed during the conflict was the 1977 CC of the Socialist Federal Republic of Yugoslavia which stipulated that crimes of the nature of war crimes could receive a sentence ranging from 10 years to death. $^{12}$

Because the Dayton Peace Agreement included the European Convention on Human Rights as part of the constitutional process, the death penalty was eliminated leading to the interpretation that this sentence was no longer possible in $\mathrm{BiH}$. However, there are judges who insist on applying the old $\mathrm{CC}$ which allows for the death penalty. ${ }^{13}$ Not surprisingly, given that different CCs have been applied, sentencing across the different courts has been inconsistent. In $\mathrm{BiH}$, there are no mandatory sentencing guidelines such as in the USA so judges can impose radically different sentences for often the same type of crime. Indeed as Azra Miletic, President of WCC Appellate Chamber notes that: "the criminal code [CC] of 2003 will not become obligatory for the entity courts...the $\mathrm{BiH}$ State Court will not oversee these trials [at the entity level] and the implementation of obligatory instructions."14

There have also been problems in how judges interpret the new code, as it is a mixture of civil and common law. Traditionally, the former Yugoslavia's CC was based on a civil law tradition in which judicial rulings were not viewed as precedent and binding on future decisions. The introduction of common law precedent in the new 2003 code has created growing pains in which judges either do not fully grasp the concept of precedent or simply refuse to follow the decisions of other courts. Moreover, the CC which was adopted in 2003 at the state level was slightly altered when approved shortly thereafter by the $\mathrm{FBiH}$ and the RS. This means that there are actually three different versions of the 2003 CC in effect. In addition, the 2003 CPC did not identify the State Court as the court of last instance in war crimes cases. Instead, the supreme courts within the entities and the appellate court in the Brcko District are still the courts of last resort for war crimes cases at the entity level.

One of the problems with the $2003 \mathrm{CC}$ and $\mathrm{CPC}$ is that like other laws in $\mathrm{BiH}$, they have been internationally constructed, which means that it is hard to create a feeling of local ownership. ${ }^{15}$ Moreover, there is a lingering perception that ethnic Serbs are almost exclusively the target of prosecution at the national level. Indeed, all of the current cases at the WCC involve ethnic Serbs, and many argue that until Bosniacs (Bosnian Muslims) are put on trial, state prosecutions will be viewed

\footnotetext{
${ }^{12}$ The Criminal Code of the Socialist Federal Republic of Yugoslavia did not include a charge of war crimes so that these crimes prosecuted today under this Code are tried under other charges such as murder.

${ }^{13}$ The application of the 1977 Criminal Code of the Socialist Federal Republic of Yugoslavia is not in accordance with the internationally recognized principle that the applicable law is that which was in effect at the time when the offense was committed unless the subsequent law is more favorable for the accused. Ironically, however, there are reports that defense attorneys have requested the trial to be conducted under the 1977 Criminal Code believing that a lighter sentence would be issued.

${ }^{14}$ Interview with Azra Miletic, President of War Crimes Chamber Appellate Chamber, Sarajevo, 18 July 2006.

${ }^{15}$ Interview with James Rodhaver, Director of the Human Rights Department, Organization for Security and Co-operation in Europe, Sarajevo, 17 July 2006.
}

Springer 
similarly to prosecutions at the ICTY (Human Rights Watch 2004). Officials at the OSCE admit that legal reform efforts have not inspired much confidence in the general public. "There is not a great deal of legitimacy attached to the courts, not a great deal of confidence in the court system, and really they are on a clock right now and sooner or later the public is going to have to see results or else you have to call into question the legitimacy of the court system."16

\section{War Crimes Cases in BiH: Judicial Capacity Building}

Because most of the attention of the international community has focused on the WCC, the capacity of other courts to try war crimes cases has been neglected. One of the mandates of the WCC was "to build domestic capacity for the prosecution of war crimes...that meet international standards of fair trial" (Registry 2005, 7). However, the WCC has no primacy over other courts, and the training of judges, prosecutors, and defense attorneys for war crimes has occurred primarily at the state level. In its March 2006 strategic plan report, the OTP of the State Court outlined a series of goals for the 2006-2009 period. Among these goals were the continuous effort to establish the rule of law, build trust among the public in the OTP, and enhance cooperation with other judicial institutions and law enforcement agencies (Office of the Prosecutor 2006). However, the measures to achieve these goals did not clearly identify how the OTP of the State Court would interact with cantonal and district prosecutors.

As the efforts of the international community have focused at the state level, the ICTY has offered a number of training programs designed to assist the WCC. However, the ICTY has viewed judicial capacity building at cantonal and at district courts as a side benefit to its training seminars, but not a core issue. While the ICTY has been concerned about the capacity of $\mathrm{BiH}$ courts to prosecute war crimes cases, particularly the 11 bis cases, it has no mandate to provide judicial capacity building to entity-level courts, and as a consequence, the interaction and relationship between the ICTY and the domestic courts can be described as limited. David Tolbert, Deputy Prosecutor at the ICTY, explains that "judicial capacity-building is something that of course the ICTY and the OTP see as an issue of interest but on the other hand, there is no specific mandate to do this."17

The section within the State Court of $\mathrm{BiH}$ that appears to be doing the most training at the entity level is the Criminal Defense Support Section (OKO). During 2005, 75 lawyers received training in international humanitarian law for war crimes trials. The OKO has projected that by 2007 , it will have trained more than 300 defense attorneys, improving the quality of defense representation in war crimes trials not only before the State Court of $\mathrm{BiH}$ but also potentially before all entitylevel courts. In addition, beginning in 2007, those individuals who are admitted as

\footnotetext{
16 Ibid.

${ }^{17}$ Interview with David Tolbert, Deputy Prosecutor, International Criminal Tribunal for the former Yugoslavia, The Hague, 12 July 2006.
} 
licensed defense attorneys will be required to complete a specific number of hours of continuing professional training each year. ${ }^{18}$

However, these training programs occur within an environment in which such basic issues as the application of the CPC are still unresolved and in which there is no hierarchical court structure that provides guidance to courts and ensures that the same laws and legal standards are applied. In addition, courts at the cantonal and the district level are severely under-funded and under-staffed. While there are approximately 13,000 investigations outstanding, there are only approximately 70 prosecutors who are actively involved in war crimes cases, and most of them do not have a full-time support staff. ${ }^{19}$ In addition, there are often no computers and limited technology available at entity-level courts. The lack of technology is especially problematic in cases in which witness protection is a concern. While the WCC has robust measures to ensure the protection of witnesses which is especially important in war crimes cases, entity-level courts have a limited ability to protect witnesses which ultimately has a chilling effect on the prosecution of the cases.

\section{Conclusions}

While strengthening the judiciary in the former Yugoslavia is an important part of the establishment of the rule of law and more generally democracy building in the region, the question remains whether these goals should have been linked to the transferring of cases from the ICTY. The devolution of cases from the ICTY to BiH as part of the Completion Strategy has contributed to the development and the strengthening of judicial institutions at the national level, particularly the State Court. In addition, the international community has been willing to make financial and human resources commitments to the WCC which will enable the prosecution of transferred 11bis cases as well as Category "A" cases returned from the ICTY. Therefore, at the state level, the Completion Strategy has provided additional financial resources and forced legal reforms which would not have occurred otherwise. However, it is questionable whether the Completion Strategy will have any profound impact at the entity level on cantonal and district courts which is where most of the war crimes cases will be tried. Cases at this level will continue to receive limited resources, and it is likely that with the enormous caseload facing these entitylevel courts, the vast majority of war crimes committed during the war in the former Yugoslavia will continue to go unpunished.

However, the problems facing the entity-level courts have as much to do with structure as with resources. The complex nature of the $\mathrm{BiH}$ government structure at all levels creates overlapping and competing jurisdictions. The creation of two entities in the post-war Dayton Peace Agreement and the further division in 1999 with the creation of the Brcko District has meant that centralizing judicial functions at the state level has been extremely challenging. The division of the country into the

\footnotetext{
${ }^{18}$ Interview with Chris Engels, Director, Criminal Defense Section of the State Court, Sarajevo, 19 July 2006.

${ }^{19}$ Interview with Toby Cadman, Head of the Prosecution Support Section, Special Department for War Crimes of the Prosecutor's Office of the State Court, Sarajevo, 19 July 2006.

Springer
} 
two entities complicates the creation of an overall $\mathrm{BiH}$ government structure. This contributes to the dysfunctionality of the government and local institutions because every issue, from courts to social welfare to the ombudsman institution, has been "negatively impacted if not down right made nonfunctional by the governmental structures here.",20

The end of the OHR's mandate in BiH in July 2007 has created an unclear transition period in which nationalist rhetoric is increasing as groups jockey for position in a post-Dayton environment. While the OHR has been working closely with its successor organization, the European Union Special Representative (EUSR) for $\mathrm{BiH}$, many in $\mathrm{BiH}$ are concerned that the transition between these two organizations will create a vacuum in which the prosecution of war crimes cases will come to a standstill. Part of this concern is due to the fact that the EUSR for BiH will be the largest EUSR mission ever, including for the first time a rule of law component. This means that the EUSR will have additional responsibilities that other missions have not previously had. Those within the OHR recognize that the creation and the transition to the EUSR means that the "credibility of the international community as well as the European Union is on the line."21

However, the EUSR will inherit a government and a judicial structure which is far from optimal. The inability to adopt similar legal norms throughout the country as well as the inability to create a hierarchical judicial structure limits the consistency in the application of the law as well as the sentencing of those convicted. These are important features not only of the legal process but more fundamentally of the integration of the country. As long as individuals view the trials and the sentencing as haphazard (or even worse, ethnically-biased), then the prosecution of war crimes cases will fail to provide an objective historical record as well as provide justice to victims and fairness to defendants. The international community and stakeholders in Sarajevo need to recognize that while Dayton was necessary to end the war, the Agreement serves as a poor blueprint for governing and prosecuting war crimes cases.

Acknowledgement Dr. Roper gratefully acknowledges the financial assistance of a Short-term Travel Grant from the International Research and Exchanges Board as well as the research assistance of Barbara Smith. Both authors also acknowledge the financial assistance of a Small Research Grant from the American Political Science Association as well as the research assistance of Liis Vahemaa.

\section{References}

American Bar Association. 2001. "Judicial Reform Index for Bosnia and Herzegovina."

Bohlander, Michael. 2003. "Last Exit Bosnia: Transferring War Crimes Prosecution from the International Tribunal to Domestic Court." Criminal Law Forum 14:59-99.

Bohlander, Michael. 2004. "The Transfer of Cases from International Tribunals to National Courts." Paper presented at the Colloquium of Prosecutors of International Criminal Tribunals.

\footnotetext{
${ }^{20}$ Interview with James Rodhaver, Director of the Human Rights Department, Organization for Security and Co-operation in Europe, Sarajevo, 17 July 2006.

${ }^{21}$ Interview with Susan Wright, Head of the Rule of Law Implementation Unit, Office of the High Representative, Sarajevo, 18 July 2006.
} 
High Judicial and Prosecutorial Council. 2006. "Capacity Assessment Analysis of the Prosecutor's Office, Courts and Policy Bodies in BiH for Processing War Crimes Cases."

Human Rights Watch. 2004. "Justice at Risk: War Crimes Trials in Croatia, Bosnia and Herzegovina, and Serbia and Montenegro."

Lauth, Mechtild. 2005. "Ten Year after Dayton: War Crimes Prosecutions in Bosnia and Herzegovina." Helsinki Monitor 4:253-266.

Office of the High Representative. 2004. "War Crimes Chamber Project: Project Implementation Plan Registry Progress Report."

Office of the Prosecutor. 2006. "Prosecutor's Office of Bosnia and Herzegovina: Strategic Plan 20062009."

OSCE. 2005a. "War Crimes Trials before National Courts of Bosnia and Herzegovina: Progress and Obstacles."

OSCE 2005b. "Background Report on National War Crime Prosecutions, Transfer of ICTY Proceedings and Missing Persons."

Registry. 2005. "Project Implementation Plan: Progress Report."

Roper, Steven D., and Lilian A. Barria. 2006. Designing Criminal Tribunals: Sovereignty and International Concerns in the Protection of Human Rights. Aldershot: Ashgate Publishing.

Zoglin, Katie. 2005. "The Future of War Crimes Prosecutions in the Former Yugoslavia: Accountability or Junk Justice?” Human Rights Quarterly 27:41-77. 